\title{
Sociopragmatic Study of Neologisms and Phraseological Expressions of Adolescents between Them and On Social Network
}

\author{
Noukio Germaine Bienvenue $^{1 *}$, Kamseu Mogo Jean Paul ${ }^{2}$ \\ ${ }^{1}$ Chercheure en Sciences Sociales, Centre National de l'Education MINRESI Yaoundé- Cameroun \\ ${ }^{2}$ Chercheur IRAD Dschang
}

DOI: $10.36348 /$ sijll.2021.v04i03.002

| Received: 24.02.2021 | Accepted: 08.03.2021 | Published: 15.03.2021

*Corresponding author: Noukio Germaine Bienvenue

\section{Abstract}

Nowadays, development takes place under different historical conditions and different places. Contemporary societies are confronted with comparable phenomena such as social breakdown, the crisis of social movements and the expansion of informal activities. Generally, written or spoken interaction appears as a means of communication, which is highly used on the social media. Youngs are writing and speaking for communication. The writing or Use of different message has a phatic and expressive dimension. These communication forms appear as a mean to chat without be with someone, to be absent but present in the group, to create intimity by preserving the usage of spatial distance.

Keywords: Communication, néologism, adolescents, internet.

Copyright () 2021 The Author(s): This is an open-access article distributed under the terms of the Creative Commons Attribution 4.0 International License (CC BY-NC 4.0) which permits unrestricted use, distribution, and reproduction in any medium for non-commercial use provided the original author and source are credited.

\section{INTRODUCTION}

Written and / or verbal communication occupies a very important place in adolescents's life. The transposition, in scriptural form, of an immediate interaction in which the meta-linguistic context remains most often inaccessible, considerably influences the writing conventions in force Draelants [1]. This is why an important dimension of the culture of "facebook, whatsapp, twiter, instagram and others" messages consists in constructing a language capable of being understood and correctly interpreted despite the absence of para-verbal cues (intonation, tone of voice, etc.) and non-verbal (facial expressions, gesture, etc.). The interactants in this communication model make use of multiple symbols incorporated in the phones in order to scripturally express the attitudes and emotions that usually fall within para-verbal and non-verbal communication. These emoticons are creative signs that enhance communication. It is these different signs that adolescents use to communicate today.

Our study will focus on the practice of juvenile interactions between them and on social networks. Many adolescents regularly send messages, frequent social networks, or belong to an internet discussion forum in which the exchange takes place mostly in scriptural mode but also in the form of audio or video recordings. While educators, trainers and parents criticize this growing way of writing for its hyper- creative character, adolescents praise it for its speed in writing, its inventiveness and its creativity in new forms of writing expression. All this would endanger the spoken and especially official languages which face the new modes of communication.

\section{The media, an essential tool in life}

The advent of New Information and Communication Technologies (NICT) has changed the lifestyles of societies both in the West and in Africa with the imperialist push. For G. Napo [2] "technological revolutions are radically transforming lifestyles, which in turn are disrupting the organization of societies".

The sociology of communication defines mass media as all the means of mass dissemination of information, advertising and culture, that is to say audiovisual and graphic techniques and instruments, capable of quickly transmit the same message to a large audience. It is all the means and techniques that a State uses to inform, train and educate its citizens. The Cameroonian media landscape will take a different look in the 2000s with the influx of mobile phones giving young people the opportunity to communicate and learn more in good time and out of time.

A companion in our daily life and an essential tool for our curiosity about the world, the media have 
become as familiar and indispensable to us today as other domestic tools or objects. We bathe every day and every hour in an atmosphere steeped in more or less disparate information, sounds and images. There is not a day, in fact, when we do not feel the need to communicate, to keep up to date with current events or simply to relax, have fun and be in contact with others through the media. Telephone or internet, no one can ignore the importance of the media these days. Through globalization, telephone and internet, young people are connecting and hearing news about various fields around the world.

\section{METHODOLOGY}

The current study was carried out using recordings, written and electronic data collected from young respondents whose ages ranged between 15 and 20 years. The young people were chosen at random without distinction of sex and school level.

\section{RESULTS}

After analysis, it emerges that all the young people contacted in our survey regularly use instant messaging and voices (audio recording) frequent various social network sites. This shows to what extent the media occupy an important place in their daily life.
When we ask them why are they adopting this form of communication? Everyone replied: it is very economical, fast and above all, mistakes are not taken into account; what is important is the message that is conveyed. The reactions of our respondents enabled us to divide their responses into five main areas.

\subsection{Familiarity between interactants}

To express the closeness between interlocutors, certain methods can be used without there being major disadvantages to listening. This is due to the closeness and familiarity between the communicators. In terms of recordings, we were able to note voices which were mixtures of French with other languages.

\section{a) Code alternation}

Code switching is a very common phenomenon in expressions used by adolescents. This "juxtaposition within the same verbal exchange, of passages where the speech belongs to two different grammatical systems or subsystems" is essentially observed in two degrees. Gumperz [3], firstly, the alternation is observed among our respondents at the level of French and pidgin-English, and also at the level of French and national languages:

Table-1: French, English and national language codic alternation

\begin{tabular}{|l|l|}
\hline French and pidgin english codic alternation & Translation in English \\
\hline La nga ci est m'bout pourquoi éééh & Why is this girl silly? \\
\hline Je peux te buy un new phone si tu me donnes... & I can buy to you a new phone if you give me... \\
\hline Si tu me put le belè je fais comment & If I am pregnant with you, what should I do? \\
\hline French and national languages codic alternation & Translation in English \\
\hline Le tapse ba'ana et le bifaga c'est la mort & The kneaded banana with smoked fish is a delicious dish \\
\hline On partage njo'o le vin même où ééé & Were do we distribute free wine ? \\
\hline Le nkoua'a n'aime pas travailler & The inhabitant of the center / south does not like to work \\
\hline Aloga donne moi un coup de main & My brother help me \\
\hline
\end{tabular}

Communicators can take this a step further by using childish pronunciations such as "cr" instead of "tr" and vice versa just because of the proximity.

For example, $\mathrm{z}$ tm cro for (I love you too much). This example can simultaneously reflect fun and hypocrisy. In the same way, the phenomena of oralization and transcription of sequences usually used in ordinary speech, or even the use of slang lexicons, aim to establish a tone bringing scripters or communicators together by a degree of familiarity comparable to that of oral conversations. . Proximity is therefore determined and accentuated by the various strategies aimed at bringing writing closer to ordinary or popular oral communication. The syntactic turns, but especially the lexicons, play a fundamental role for this discursive function. Note that the proximity function is manifested to different degrees depending on the knowledge of the communicators in the case of private exchanges and the place of communication.

\section{b) Neologisms}

This concept covers two aspects: the first says Dubois [4], designates the phenomenon which "consists in using a signifier existing in the language considered by conferring on it a content that it did not have until then". We count a large number of neologisms among our respondents. 
Noukio Germaine Bienvenue \& Kamseu Mogo Jean Paul., Sch Int J Linguist Lit, Mar, 2021; 4(3): 73-79

Table-2: Neologism and translation

\begin{tabular}{|l|l|}
\hline Neologisms in French/ English & Appropriate translations \\
\hline Je t'ai absenté hier & $\begin{array}{l}\text { Je t'ai manqué hier. } \\
\text { I missed you yesterday }\end{array}$ \\
\hline $\begin{array}{l}\text { Jean a baptisé le barman } \\
\text { John baptized the barman }\end{array}$ & $\begin{array}{l}\text { Jean n'a pas payé sa consommation chez le barman. } \\
\text { John did not pay for his drink at the bartender }\end{array}$ \\
\hline $\begin{array}{l}\text { Tu m'as bondi lundi. } \\
\text { You jumped me on Monday }\end{array}$ & $\begin{array}{l}\text { Tu m'as donné un faux rendez-vous lundi. } \\
\text { You gave me a fake date on Monday }\end{array}$ \\
\hline $\begin{array}{l}\text { Samedi, tu composes tes parents avant de sortir. } \\
\text { Saturday, you compose your parents before going out. }\end{array}$ & $\begin{array}{l}\text { Samedi tu convaincras tes parents avant de sortir. Saturday } \\
\text { you will convince your parents before going out }\end{array}$ \\
\hline $\begin{array}{l}\text { La coyotte là est très courte. } \\
\text { This coyot is very short }\end{array}$ & $\begin{array}{l}\text { La fille de joie/prostituée est de petite taille. } \\
\text { The maid / prostitute is too short. }\end{array}$ \\
\hline $\begin{array}{l}\text { C'est moi qui gère la petite ci maintenant. } \\
\text { I'm the one running this little one now }\end{array}$ & $\begin{array}{l}\text { Je suis le copain de cette fille. } \\
\text { I'm this girl's boyfriend }\end{array}$ \\
\hline $\begin{array}{l}\text { Son père a le gombo mal mauvais. } \\
\text { His dad has bad bad okra }\end{array}$ & $\begin{array}{l}\text { Son père est riche/il a beaucoup d'argent. } \\
\text { His dad is rich / he has a lot of money }\end{array}$ \\
\hline $\begin{array}{l}\text { L'enfant a posté au couloir. } \\
\text { The child has posted in the hallway }\end{array}$ & $\begin{array}{l}\text { L'enfant a fait les selles au couloir. } \\
\text { The child has made a stool in the hallway. }\end{array}$ \\
\hline $\begin{array}{l}\text { Dès que tu dames tu me retrouves. } \\
\text { As soon as you chop you find me }\end{array}$ & $\begin{array}{l}\text { Dès que tu finis de manger tu me retrouves. } \\
\text { As soon as you finish eating you find me }\end{array}$ \\
\hline
\end{tabular}

As for the identity of communicators, it is defined in relation to the opinion that each individual has on the writers. On the basis of linguistic productions, nicknames and social networks play an important role of socialization and identification in recognition between young people. In terms of linguistic statements, it is the lexicon used that defines the identity of others. However, in the case of messages, the language and abbreviations used are unique to the initiates because who is not, will not understand or read anything. This is the most marked case of an identity group observable on the network, the atypical writings connoted "SMS language" not presenting in such a pronounced manner an insider language that is difficult to access. Moreover, for Dejond [5], the feeling of mastering complex jargon gives the impression of belonging to a particular group. Take the example of one of our interviewees to better elucidate the phenomenon of identity and proximity.

John: slut mn pot, how, if ta 1 fè 1 mwa savwa kar j veu kn kmnik dm1 SWR aprm 1 sKoool (Translation: Hi my friend, how are you? If you have it, let me know, because I want to communicate tomorrow night after school)

Paul: $1 \mathrm{P} € \mu$ Biøoo1, mè you will wait because I work my sixt A F7R I let you go as soon as q released tInkièt; http; // iokonoo .net

(Translation: a little surprised, but you have to wait because I have my sister's job to do. I will call you back when I am free. )

Do these examples reflect the identity of the interactants which is defined by the atypical form of the words? Considering that atypical writings connoted
SMS language, kikoo-lol language, or other language, are recognizable by characteristic graphic features such as smileys, acronyms, abbreviations, etc., we are not in a position to say that atypical writing is the reflection of a particular group because the advent of the Internet has made everyone stick to the new scriptural mode of "sound". Young people, within their community or among friends, use different scriptural and oral forms. In short, we can say that knowing the identity of one or more young people depends on the different styles used by this or them because the language used is practiced in a specific context.

\section{3-2. Expressiveness of the message}

The semantics can remain fuzzy or polysemous, without much consequence on communication, since the use of enunciative markers guides the work of interpretation of the receiver. One could also hypothesize that, in peer-to-peer conversations, the meaning of the message is largely absorbed by the form in which it is expressed. The phatic dimension often outweighs the informative intention.

In line with the work of J. Gumperz on the role of linguistic variation in interactions, we find that the fact of moving, in the same conversation from one language to another (or from one register of language to another) can be explained in particular by cultural conventions, expressive intentions and communication strategies through which each person's place in the interaction is played out. Of course, the extent of these variations depends on the linguistic resources available to everyone. Individuals draw on a "language repertoire" which is not infinite. Depending on the limits authorized by his sociolinguistic habit (Bourdieu [6]), a speaker may mobilize a greater or lesser number 
Noukio Germaine Bienvenue \& Kamseu Mogo Jean Paul., Sch Int J Linguist Lit, Mar, 2021; 4(3): 73-79

of lexical, syntactic, morphological variants which he will make differentiated use according to the context of the interaction. a) Derivative prefixation and suffixation

These are formations of new words by adding prefixes or suffixes to already existing words:

Table-3: derivative prefixation and suffixation words

\begin{tabular}{|l|l|l|l|}
\hline Préfixation & Words & Suffixation & Meanings \\
\hline Dés & intester & $/ / /$ & $\begin{array}{l}\text { Vider l'animal de ses intestins } \\
\text { (Empty the animal of its intestines) }\end{array}$ \\
\hline Dés & slipper & $/ / /$ & Oter le slip (Take off the underpants) \\
\hline Dé & gammer & $/ / /$ & $\begin{array}{l}\text { Faire ou dire quelque chose de maladroit } \\
\text { (Do or say something awkward) }\end{array}$ \\
\hline$/ / /$ & science & cer & $\begin{array}{l}\text { Réfléchir sur un sujet ou sur quelque chose } \\
\text { (Think about a subject or something) }\end{array}$ \\
\hline$/ / /$ & White & iser & Parler comme un Parisien. (Speak like a Parisian \\
\hline$/ / /$ & ambiance & eur & $\begin{array}{l}\text { Individu qui anime, qui aime faire la fête. } \\
\text { (Individual who animates, who likes to party) }\end{array}$ \\
\hline /// & Sieste & er & Se reposer, dormir. Rest, sleep \\
\hline
\end{tabular}

Apart from derivational prefixation and suffixation, adolescents also use other linguistic procedures such as the abbreviation (Asso for associate, titus pour titular, cop's for friend), acronyms (BCO for BEPC; BH for pof pof and bean) ) and improper derivations.

"Context" effects and "socialization" constitute two dimensions that are absolutely inseparable from our social practices in general (Lahire, [7]), and from our language practices in particular.

To convey emotions or signify astonishment, young people use several scriptural styles (devoid of any meaning in writing) but which mean something specific to Internet users. Certain graphic processes are implemented such as the use of capitals to highlight an element, or to shout in chats and in forums.

\section{Example: EKIEEEH THIS MAN WILL KILLLL MEEE}

We can spot graphic stretches to emphasize an element of speech or to transcribe the pronunciation of a language sequence. We distinguish two types of graphic stretches: the first consists of repeating one or more letters in a graphic sequence, and the second consists of repeating a punctuation mark. Here is an example illustrating the two phenomena:

\section{Example: WOULILILILILILILI!!!!!!!!!!!!!!!!!}

We speak of graphic stretching when the sequence reproduced is greater than a graphic sign or a minimum unit of meaning.
So the sequence (gran) reproduced in the following example is a repeat: grangrangrangrangrand merci (thank you)! Expressive processes are therefore manifested in various ways and have the specificity of bringing to light the peculiarities of ordinary and popular oral discourse, to use the terminology of Gadet (1989 and 1992), in written productions. Expressive processes are used less in written messages but more in audio recordings.

\section{3-3. Ornamental and funny function}

In the digital age, adolescents, thanks to modern means of communication, play in many ways with the use of words. The goal is to adorn the messages. It is about standing out from other writers by a linguistic originality such as puns or the use of terms having a sound other than French. One of the less linguistically structured variations is this language that adolescents use to communicate. This language, which we cannot qualify, is riddled with mistakes, enunciative singularities, morphosyntactic sprains and phonetic incongruities.

DASSI [8] defines linguistic particularism as "a phenomenon which tends to be confined to a geographical area. It is a departure from the normative or codified practice (not marked by the language)"several cases of these linguistic mores punctuate the communicative praxis of adolescents in their daily life. 
Noukio Germaine Bienvenue \& Kamseu Mogo Jean Paul., Sch Int J Linguist Lit, Mar, 2021; 4(3): 73-79

Table-4: Funny expressions

\begin{tabular}{|l|l|}
\hline Words and expressions & Meanings \\
\hline Cette fille a un derrière l'eau-l'eau. & Cette fille a des fesses à la peau flasque. \\
This girl has flop flop behind & This girl has saggy buttocks. \\
\hline C'est comment nooon. & Comment vas-tu ? \\
This is how nooo. & How are you ? \\
\hline Goûte-moi le truc là. & Fais- moi gouter la nourriture. \\
Taste me the stuff there. & Let me taste the food etc. \\
\hline L'épreuve de maths là était jinja. & L'épreuve de maths était difficile. \\
The maths test was jinja. & The maths test was difficult. \\
\hline Cette femme à la gueule. & Cette femme bavarde beaucoup. \\
This woman has a big mouth. & This woman talks a lot. \\
\hline J'ai vu aujourd'hui mama. & Maman j'ai vu quelque chose d'incroyable. \\
I saw today mama. & Mom, I saw something amazing / horrible. \\
\hline Il se croit beaucoup. & Il est très orgueilleux. \\
He believes himself a lot. & He is very proud. \\
\hline Ne me taxe pas la chaussure ci. & Ne me vends pas la chaussure chère. \\
Don't tax me on that shoe. & Don't sell me the expensive shoe. \\
\hline
\end{tabular}

As we can see, this series of sentences is made up of French words but in a particular way. In this case, it will be necessary to see these expressions as simple expressions whose function is communication by freeing from normative constraints. Bickerton in tripartite typology asserts that university campuses have over the years become veritable linguistic melting-pots where all these different styles of communication abound and finally generate jargon with crypto-fun value as demonstrated by FOSSO [9] from of the vocabulary of sexuality in a student environment.

Some adolescents write ornamental speeches by oscillating between upper and lower case, using particular characters, or even using graphic signs other than letters such as numbers, punctuation, or the like, to replace them more or less systematically. Unintentionally, the communicating writer himself encrypts his message using these various scriptural ways. Note that the use of particular signs is regular, and that their use functions as an encryption key where each sign replaces another.

John: Hey men we're s®an in Kammmmm??? REME has kOOOOOOOk wht $\bigvee u$ there is floooop peoples

(Translation: hi Guys are we moving /meeting together at home? Mom has prepared what you like and there is a lot of people)

Paul: Yepp i'll follow b €t 1sst BKrai fr us Tèk wn wai fr do $£ \beta \Omega$ ndr la $t ¥ \Omega$ p (Translation: okay I will be right there, but first I will go to the bakery and get us something to go with the meal.

John: Koooool see uuuuu (Translation: fine later) Paul: 'am (I am happy)

\section{3-4.Cryptic function}

The writer unwittingly uses cryptic devices in a restricted graphic space of his speech. Especially since these atypical writings are considered to be acts to be shared with a more or less large community of users of the means of communication, or with a particular receiver in the context of private means of communication. Cryptic function is therefore not fundamentally considered as for sociological slang (Goudaillier, [10]), despite the shared knowledge of writers both lexically and graphically. In cryptic writing, young people use several methods so as not to be heard by adults. In this specific case we can speak of a young identity because here the standards are totally flouted. A similar analysis can be put forward to account for writing practices. Depending on the writing context (medium, identity and status of the receiver, expressive intention, school or extra-curricular context, etc.), the adolescents questioned sometimes use a sustained language with a complex syntax and an elaborate vocabulary, sometimes a more relaxed, strewn with English words, abbreviations and invented words. More interestingly, there is variation even within some written speeches. This alternation can give more clarity or more force to the speech, when the speaker takes some freedom with regard to the standards of standard French. We know, since Dell Hymes [11], that "communication skills" cannot be confused with "grammatical skills". One can very well use the language in a grammatically correct way without being understood, heard or taken seriously by the interlocutor. Conversely, we sometimes communicate effectively while blithely deviating from the rules governing the "proper use" of French. The standards that govern conversation are not those set by standards prescribers. The adolescents we have met, expressed themselves in different manners. First of all, by means of a rather fine linguistic analysis, we could show that they adjust, more or less, their language to the context of interaction, to the proximity maintained with the 
Noukio Germaine Bienvenue \& Kamseu Mogo Jean Paul., Sch Int J Linguist Lit, Mar, 2021; 4(3): 73-79

receiver and to his social status (" For less important people, I write with simpler words but without fail, I try to be careful", explains one interviewer). The prioritization of recipients is also effected through sometimes subtle distinctions. However, the use of variation appears to be much more frequent when comparing distinct interaction situations within the same interaction situation. Let us observed the conversation between John and Paul.

John: Helloooooooooooooooooooooo:

Paul: How r U 2day (how are you today)?

John: not bad \& U (not bad and you)?

Paul: it moves my big 1 (a)

John: MDR X)

Paul: we call each other in the evening because I am tvl

$\ldots=\mathrm{s}$

John: Yepp ...: /

Paul: A dm1 <3

John: A $2 \mathrm{~m} 1<3$ x 10000000000

Paul: Hello: J, U can come to my place around 1 p.m. $\ldots=\mathrm{P}$

John: Ok I'll arriv then :)

Paul: Ok alz

John: What R U doing, litl rat?

Paul: I put on my pijamas and you? xD

John: I'm watching TV

Paul: Mnt me too

John: What $r$ U looking at?

Paul: It's all explained and you?

John: Same: P

Paul: Did U get yelled at on your way home?

John: Yes, my riding cabinet was in a mess! $\mathrm{x}$ )

Paul: Haha xD x ')

Comment: By analyzing this exchange, one observes important variations of language. Everyone intentionally uses loose language when communicating: "Abbreviations are for my friends so I don't give them any weight with regards to mistakes ..."

\section{3-5. Economic axis}

The scriptural ways in which young people communicate today are too abreviative. In messages, writing in an atypical manner does not keep the correspondent waiting. Anis [12] and Lorenz [13] call special graphic styles such as the mixture of letters, numbers and other graphic signs rebus; and, the excessive use of the letter " $\mathrm{k}$ " for the sound [k]. Let us analyze the following examples given by our respondents:

John: $\mathrm{k}$ di tu d 7 meuf $\mathrm{lm}$ plè (translation: What do you think about this girl, she interests me.) Paul: tè pa busi des nga twa oci (translation: You are not tired of women, you too!) John: fèr 1 peu cè pa movè (translation: Making love with her is not bad!) Paul: ola spa b1 dtapar (translation: Oh la la, that's not good from you.)
John: Slt c chèk cè mn aniv ojrd8. si t sur mn blog tu va si tt lè foto of my friend and of no delirium !! $\mathrm{A}+$ pr dè nws! J vs less yeuté trankil .... bizzzzzzzzzzzzzz!!

(Translation: hi it's John, it's my birthday today. If you're on my page, you'll see photos of my friends and our follies. See you later for more news. I leave you, and I kiss you).

Analyzing these two examples, we notice like Michot [14] that these young people use word compression and many abbreviations. For example, removing letters at the end of a word: pa (pas); di (dis); j (je); n (ne).

Skeletal consonants: mn (mon); pr (pour); vs (vous)

Logograms: 2m1 (tomorrow), b1 (good); ojrd8 (today); 7 meuf (this woman) -The addition of more or less complex words: tèpa (you are not), spa (it is not). For us, through these examples, we show how young people use short or even abbreviated styles to communicate. From one correspondent to another, we can notice some differences either because of writing habits, or because of the situations in which they may find themselves.

\section{DISCUSSION}

As much as we recognize it, communication remains a unifying factor, but its practice is constantly a field of confrontation between two universes: the local polyglot universe, characterized by the coexistence of several languages and the unilingual administrative universe, characterized by a hierarchy, which gives the official language, the language of instruction and writing, a privileged status over other languages that are also rooted in local cultures. Diglossia therefore appears as the obligatory sociolinguistic chassis because it poses the problem of language in relation to cultural identity. How can the speaker, heavy with a rich and varied substratum, faithfully express local realities, his daily life, externalize his being to the world through French, another language without, however, disguising it?

Sociolinguistic studies demonstrate this enough: a language that does not get rich, that does not acquire new speakers, withers away.

\section{CONCLUSION}

Throughout this analysis, we have shown how young people use graphics of all kinds to communicate. Sure, young people want to look good, do it fast, may be do it too well by giving themselves another image and much more original but at what price? If the standardization of this type of language is not adopted one will move in the coming years to the loss of conventional writing and speaking. Oral and written practices are far from deserting the daily lives of the adolescents surveyed. They make intensive use of new 
Noukio Germaine Bienvenue \& Kamseu Mogo Jean Paul., Sch Int J Linguist Lit, Mar, 2021; 4(3): 73-79

modes of communication and devote a considerable portion of their time to written communication with their loved ones. These new modes of communication foster the development of a relatively functional relationship to writing. To be ecstatic about the "creativity" of new forms of linguistic communication is to forget that the language of Internet users and its avatars have not magically wiped out the classifying power of our cultural judgments. Apparently the most 'liberated' young people in their speaking and writing habits are sometimes also the most quick to become guardians of the spelling temple. In fact, it is still through the transmission of metalinguistic skills that the younger generations are likely to be offered the opportunity to develop a reflective relationship to language and a fine understanding of the political issues that run through it.

\section{REFERENCES}

1. Draelants, H. (2004a). Juvenile uses of communication technologies. New ways of being together and socializing. The Observatory - Social $\&$ medico-social action review, $\mathrm{n}{ }^{\circ} 43$, JulyAugust-September.

2. NAPO, G. (2005). Impact of media sexuality on adolescents in urban areas in Togo, master's thesis in sociology, UL, Lomé Togo.

3. Gumperz, J. (1989). Start a conversation. Paris: Les Editions de Minuit.

4. Dubois, J. (1994). Dictionary of linguistics and language sciences, Paris, Larousse.

5. Dejond, A. (2006). Cyberlangage, Brussels, Racine.
6. Bourdieu, P. (1982). What to speak means. Paris: Fayard.

7. Lahire, B. (2001). The sociological work of Pierre Bourdieu: Debts and Criticism: The discovery.

8. Dassi, E. (2003). "Question of semantics: neology around telephony in Cameroon", Languages and communication, $\mathrm{n}^{\circ}$ 3- volII, Yaoundé, Saint-Paul, $139-153$.

9. Fosso. (1999). "Lexical creativity on the Yaoundé I university campus: study of the lexical field of sexuality", French in Black Africa, $\mathrm{n}^{\circ} 3$, http: /www.fr/ILF-CNRS/fosso.htlm, date of consultation 15 January 2021.

10. Goudaillier, J.P. (2001). Comment tu tchatches! Dictionary of contemporary French for cities, 3rd edition, Paris, Maisonneuve and Larose.

11. Hymes, D. (1991). Towards communication competence. Paris, Hatier.

12. Anis, J. (2003). Electronic scriptural communication and language forms: chat and SMS, Proceedings of the Fourth Meetings of Human Networks / Technological Networks (May 31 and June 1, 2002), University of Poitiers 139P.

13. Lorenz, P. (2010). (Forthcoming), Examples of the language identity of cybernauts: rebuses and graphic games in the chat, Brno.

14. Michot, N. (2008). The graphic representations of the lexicon in the atypical written practices of young people, 1st World Congress of French Linguistics: Acts of the Congress, Durand J., Habert B., Laks B. (dir.), Paris, La Cité Internationale Universitaire, 1163-1177. 